\title{
ENVIRONMENTAL COOPERATION OF UKRAINE WITH BALTIC COUNTRIES IN WASTE MANAGEMENT PROJECTS.
}

\author{
Mykhaylenko Valeriy \\ Taras Shevchenko National University of Kyiv, Ukraine \\ Hoffmann Michael \\ Institute of Water Problems and Land Reclamation NAAN, Ukraine
}

Denafas Gintaras

Kaunas University of Technology, Lithuania

Alekseyevets Ivan

"Clean City”, National project under auspices of President of Ukraine, Ukraine

Ludwig Christian

Paul Scherrer Institute, Switzerland

Ogorodnyk Stanislav

Kyiv University of Management and Entrepreneurship, Ukraine

Martin Garry

Association of Ukrainian Cities, Kyiv Regional Office, Ukraine

\begin{abstract}
Ukraine is one of the largest countries in Europe that has numerous environmental problems due to backward technologies and strong influence of the former totalitarian system. The article seeks to consider the current status of Ukrainian environmental policy and disclosing the idea of "environmental cooperation" with Baltic countries in scope of MSWM. The strategic route of Ukraine towards sustainable society and joining the EU determined the relevance of MSWM as one of the most substantial environmental impacts. Foreign experts note a significant backlog of Ukrainian MSWM compared to EU standards. Engineering studies that are the basis for decision-making authorities are in a very early phase of development. Household landfills are a significant source of greenhouse gases, leading to losses of land and spreading of dangerous compounds to surrounding water flows. The authors are outlining benefits of environmental cooperation to Ukraine and BSR countries at both international and local levels. Examples of donor assistance that Ukraine already obtained from Poland, Lithuania, Denmark, Sweden, Finland and Norway are discussed. Unfortunately, collaboration with Western countries very much depends on the political will of Ukrainian authorities. To the date, Ukraine does not meet a sufficient progress in obtaining the status of an associate EU member in spite of the announced cooperation strategy. In view of this, environmental cooperation at the regional and local level seems to be a key issue for Ukraine on its way towards sustainability and developing principles of democracy and market economy. Strong relations with Baltic countries are creating a good basis for overcoming
\end{abstract}


environmental problems at regional and community level and may form a first pilot model of ecological security.

\section{KEYWORDS}

Environmental cooperation, Baltic countries, solid waste management, landfill, sustainable development, recycling, technical assistance, Ukraine

\section{LIST OF ABBREVIATIONS}

BSR - Baltic Sea Region; CBC - Cross-border Cooperation; DABLAS Danube - Black Sea; DANCEE - Danish Environmental Assistance to Eastern Europe, DEPA - Danish Environmental Protection Agency, DEA - Danish Energy Agency; EECCA - Eastern Europe, Caucasus and Central Asia, ENPI - East - European Neighborhood and Partnership Instrument; EU - European Union, HELCOM - Helsinki Commission; GDP - Gross domestic product; IFIs - International Financial Institutions; LG - local government; MENR - Ministry of Environment and Natural Resources of Ukraine; MOU - Memorandum of understanding; MSWM- municipal solid waste management, NEFCO - Nordic Environment Finance Corporation; SD - sustainable development, SIDA - Swedish International Development Cooperation Agency; SwEPA - Swedish Environmental Protection Agency; TACIS Technical Assistance to the Commonwealth of Independent States;

\section{STATE OF AFFAIRS IN UKRAINE}

MSW related problems are faced by all countries and open up opportunities for international cooperation [1]. Such issues include waste management (prevention, collection and treatment) together with hazardous waste, energy efficient technologies, greenhouse gas emissions and water pollutions. Ukraine is the second-largest country in Europe with an area of 603,700 sq. $\mathrm{km}$. Although independence was attained in 1991, strong influence of Russian policy remains as many of the former Soviet elites remain entrenched and stall efforts at economic reforms, privatization, and civic liberties. Nevertheless, Ukraine officially declared its willingness to join the EU.

The waste related issues belong to the biggest environmental problems of Ukraine. The oldfashioned system doesn't take account of European countries' experiences. The existing management is based on the 1970s' ideas and focused on waste landfilling without proper pretreatment. Dumps cover 8.1 thousand hectares (ha) [2] of Ukrainian land. Nowadays Ukraine is facing large-scale social and political changes that give the chance to modernize the country on the basis of fundamental trends of SD. Ukraine realizes that environmental protection will be amongst the most important and complicated categories to complete the negotiations with the EU [3].

Only $4 \%$ of total waste amount is burned at two outdated incinerating plants [4]. Two additional plants were stopped as dangerous for humans and environment. Separate MSW collections are implemented in 130 out of 450 Ukrainian cities as a pilot projects [2]. The first waste sorting station was built in Kyiv in 2005 with a capacity of 250 thousand tons of MSW processing per year.

Currently more than 50 regulations on state level (14 of the Law of Ukraine and about 30 governmental decisions and orders), are adopted to gradually approach the requirements of 
European legislation. Unfortunately, their enforcement needs much effort. The approval of State environmental policy of Ukraine till year of 2020 [5] has become a huge breakthrough in the field of national environmental legacy. Such a fundamental document has not been adopted in the field of environmental protection for decades. The new strategy aims to complete the formation of a national legislative base and complement it with further improvements with regard to EU regulations.

The current government of Ukraine has taken drastic measures towards to decrease the problem of low MSWM efficiency. The Presidential Decree N 31/2010 of January 15, 2010 obligated responsible authorities to develop and consider the National Program of waste management. Starting in May 2011, the Cabinet of Ministers' Decree obliged all home and land owners, as well as service providers of waste disposal, to introduce separate waste collection with the aim at recycling.

Today, we observe the development of a waste processing industry that will take care of sorting, recycling and utilization of MSW. Ten modern MSW sorting and recycling complexes at main Oblast cities are planned within the project "Clean city" that started recently under the auspices of the President of Ukraine. The commercial part of the project foresees mechanism of public-private partnership. The amount of State financing is 5 billion Ukrainian hryvnas.

\section{ENVIRONMENTAL COOPERATION}

Environmental cooperation plays an important role in international diplomacy as it is the only possible way to solve national and also global environmental problems. The objective of Ukrainian cooperation with BSR countries is consolidation of fair and SD, and harmonization of environmental legislation with EU standards. The development of Baltic prospects will certainly help Ukraine to be integrated faster into the EU and promotes the participation in EU projects [6].

The European Commission has been the largest donor of environmental assistance to the EECCA region during the period 1996-2001, accounting for about $17.8 \%$ of the total. In 2001, the EC provided $€ 21$ million to environmentally-related assistance in EECCA. Denmark together with, Sweden, Norway, Germany and Finland have also been major donors.

Almost $€ 4$ bn. out of the $€ 12$ bn. of the European Neighborhood and Partnership Instrument (ENPI - East) funds have been allocated for Eastern neighbor countries in 2007-2013. Ukraine and Russia are the largest recipients of environmental assistance, together accounting for more than two thirds of the total. During the years 1996-2001, Ukraine received $€ 102 \mathrm{mln}$., and Russia $€ 317 \mathrm{mln}$. [7]; reporting on related expenditures is minor.

The EC regional assistance in the framework of the ENPI has the focus on developing 15years integrated waste management strategies referring to a sustained management of solid waste through the use of a comprehensive integrated strategy. The overall project objective is to reduce the risks arising from inappropriate waste management to reduce environmental pollution through partners' co-operation in the region. The five main directions of the project are: Inventory of illegal waste disposal sites; Strengthening waste classification practices; Development of pilot region waste management strategies; Feasibility study on establishing a 
"DABLAS type" platform; Public awareness, Information dissemination and capacity building [7].

The total environmentally-related expenditure, as a share of GDP is a good indicator of the commitment to environment because it indicates the share of income that a country is willing to devote to environmentally related purposes, see Figure 1. It reflects the priority assigned to the environment in the country's economy, depending to what it can afford.

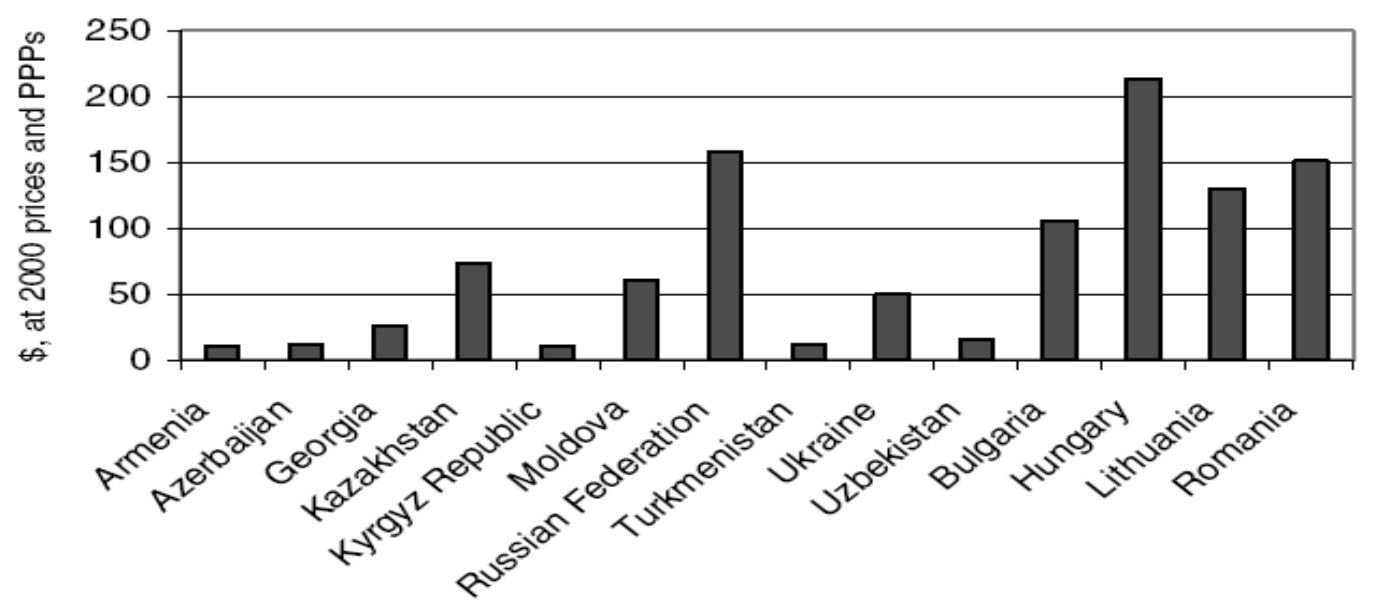

Figure 1. Environmenally related expenditures per Capita in EECA, average 1996-2000. Source: Eurostat, national statistics, OECD, WB.

Despite of the official non-acceptance of the "The Agenda XXI", Ukrainian authorities have drawn the strategy of national environmental policy for the period up to the year 2020 based on SD principles. In the EU/Ukraine Action Plan accepted by the government in December 2004 the SD-concept is defined as an important long-term objective [3]. The necessity of introducing a new environmental policy complies with a number of international obligations of Ukraine. This appears to be a mandatory clause to reach the Millennium Development Goals, as well as others regulations of international global and regional environmental conventions ratified by Ukraine.

\subsection{International Environmental Agreements}

Throughout the 90s Ukraine has signed or ratified more than 70 bilateral and regional environmental agreements, which obligates the State Government to certain actions [8]. The most significant ones that already come in force in Ukraine and coincide with MSWM are the following: Climate Change (1997), Espoo (1999), Basel (2000) and Rotterdam (2004) conventions, Kyoto Protocol (2005), Landscape (2006) and Stockholm (2007) conventions. These global international threats are assuming safe waste operations, broadening of information channels, raising awareness of civil servants and ensuring public participation in decision-making processes in compliance with the Aarhus Convention, valid from 2001. 


\subsection{Regional cooperation}

Two projects entitled "Capacity Building in Waste Management" were introduced in Donetsk Oblast with TACIS support, aimed at introducing a new approach to solving the MSWM problem. Within the first project phase the Regional Strategic Plan for MSWM was elaborated and adopted by Donetsk Regional Council in 2005. During its second phase the LG officials received support to introduce changes in waste management in their cities such as separated MSW collection, development of local waste action plans and public awareness rising.

A four year regional project "Waste Governance - ENPI East" was launched at Zakarpattya Oblast in December 2010. The project aimed at developing a 15-year integrated strategy for the sustained MSWM. The specific project objective is "to improve the management of waste by promoting higher standards at waste facilities, more effective waste prevention initiatives, increased capacities for waste collection and sorting, as well as increasing reuse, recovery, and safe disposal of waste".

\subsection{Cross-border cooperation}

The CBC Program Poland-Belarus-Ukraine 2007-2013, under the ENPI aims at broadening cooperation in the near-border areas of the three countries. A large part of the PolishBelarusian-Ukrainian borderland is located in the so-called "Green Lungs" of Europe and contains areas of outstanding landscape and nature with low pollution. The environmental protection infrastructure of this area is inadequate. Many villages and smaller settlements lack waste-water treatment systems, modern waste collection systems and landfills [9].

\section{UKRAINES' COOPERATION WITH BSR COUNTRIES}

Historically, Lithuania, Poland and Ukraine have had close ties and common cultural heritage. Consequently, the experience of our neighbors is comprehensible and applicable for Ukraine to the greatest degree. For the first time since the disintegration of the USSR, the need of cooperation with BSR countries was pointed out by the former Lithuanian President A. Brazauskas in 1997. The EU enlargement that took place on the May $1^{\text {st }}, 2004$, has resulted in historical changes of political, geographical and economic matters both for Ukraine and EU. Being direct neighbors, Ukraine and EU are in need to renovate their political, economic and environmental cooperation. There were a lot of bilateral and broader initiatives, some of them are presented below.

\subsection{Poland}

Waste management is a matter of central concern to BSR countries. "Baltic Ukraine"- is the subject considered by politicians since 1991 when the BSR Program was started. This is a concept of forming a northwestern direction of European integration for Ukraine heavily depending on the political will of Ukrainian authorities. Only few people realize that Ukraine has much more impact on the quality of Baltic Sea environment than Estonia. The tributary to the Western Bug that belongs to the Baltic Sea basin is much polluted by the Poltva River. It carries drainage water from the landfill of the city of Lviv where about 800 thousand people live. Small towns and villages in the "Baltic" part of Lviv and Volyn regions (oblasts) as Sokal, Chervonograd and Novovolynsk should also be taken into account. All cities together make up almost 1.5 million inhabitants, the same amount of inhabitants as the whole Estonia. Ukrainian communities are seeking a way to cooperate with Baltic countries considering that scientific, economic and political issues may remove the obstacles on the way to SD goals. In 
March 2008 the Lviv Oblast council called the Ministry of Foreign Affairs and the Verkhovna Rada (Parliament) of Ukraine to join the Helsinki Convention on the Protection of the Marine Environment of the Baltic Sea Area. As a Party of Helsinki Convention, Ukraine may apply for HELCOM grants, aimed at relieving environmental impacts of Lvivska and Volynska regions.

\subsection{Lithuania}

Being part of the EU, Lithuania gained both positive and negative experience in modernization of MSW management that Ukrainian government should take into consideration. There were appreciable errors and difficulties along with evident progress that are typical for new CEE countries EU members. For example, when the internal Lithuanian legislation was adapted to the EU directives and modernization of the systems of waste management was realized, the National Strategic plan of waste management was developed. Wide ranges of state and regional projects were launched and regional centers of MSWM established; sites for separately collected green waste were brought into service. Systematic expansion of separate collection and recycling of municipal solid waste still goes on. However, a number of internal political issues caused problems for the practical realization of reducing food waste depositing, as well as for mechanical, biological and thermal MSW treatment.

The multi- lateral scientific project entitled "Seasonality of Municipal Waste Generation and Composition and Corresponding Fluctuations of Various Environmental Indicators for Waste Management and Treatment Facilities" (SWC-ENV-IND) has been launched by Kaunas Technological University (KTU), Lithuania, simultaneously in five countries: Lithuania, Ukraine, Russia, Georgia and Switzerland in December, 2009. It focuses on finding socioeconomic trends in MSW generation and predicting several engineering parameters for its processing. This analysis will allow establishing methodologies for a more adequate forecasting of environmental impact and economic feasibility for existing and planned MSW management systems. Within this project there are opportunities for expanding of strategic and scientific approaches, adopting the best EU experience related to MSWM. The project started with financial support of the Swiss National Scientific Fund [10].

The scientific interests of Ukraine in this field were actively discussed at the International conference «Sustainable solid waste management in Eastern Europe: prospects for the future» [11] that took place in Kyiv, in May, 2011. The main objective of the conference was to deepen the international cooperation in the field of MSWM through involving Ukraine's governmental, business and public organizations into the discussion of waste management strategies with experts from EU and CIS countries. The scientific input of KTU was acknowledged as a priority in the field of engineering research and resulted in signing a bilateral agreement on scientific and technical cooperation between the Taras Shevchenko National University of Kyiv and the KTU in the field of MSWM and forecasting of waste seasonal deviations. Thus, the Parties will be able to implement the project outcomes and practical recommendations on the way to saving natural and urbanized landscapes and promoting education in the field of environmental engineering and MSWM.

Joint researches were conducted towards the improvement of MSWM methods, including energy use and landfill gases generation on the basis of studying seasonal morphological changes of waste and its heating value. The Parties have founded a Consortium aiming at promoting scientific researches in the field of environmental engineering and management with leading role of KTU. 
The scientific and educational contacts between Poland, Lithuania and Ukraine, in light of enlargement of the EU were also actively discussed at the International Scientific Conference that took place at Chernivtsi National University in 2008. It aimed to consider the present state of scientific and educational contacts between state institutions and non-government organizations, produce particular proposals on the establishment of bi- and multilateral relations, and determine possible common projects. It was noted that mutual relations may create a new communication platform between researchers in these countries.

\subsection{Denmark}

Scientific and technical cooperation between Ukraine and Denmark has been actively developed since 2001. It is coordinated by DEPA together with DEA and certain consulting firms [12]. DANCEE-Country Program for Ukraine (2002 - 2004) was launched to strengthen national environmental policy in Ukraine in order to implement the strategy for the environmental assistance to Eastern Europe. There were 82 projects have been introduced in Ukraine by DANCEE funded companies from 1994 till 2005. The cooperation resulted in pilot projects of factories processing toxic waste in industrial regions of Ukraine, and providing "clean technologies" in engineering industry [13]. A number of projects were directly related to the solid waste sector, see Table 1.

\begin{tabular}{|c|c|c|c|c|}
\hline \multirow[b]{2}{*}{ \# } & \multirow[b]{2}{*}{ Project name } & \multirow[b]{2}{*}{$\begin{array}{l}\text { Supervising } \\
\text { Ukrainian Authority }\end{array}$} & \multicolumn{2}{|c|}{ Financing in Euro } \\
\hline & & & DEPA & $\begin{array}{c}\text { Other } \\
\text { sources }\end{array}$ \\
\hline 1 & $\begin{array}{l}\text { Environmental identification mission on } \\
\text { hazardous waste }\end{array}$ & MENR & 129449 & - \\
\hline 2 & Cleaner technology, pre-study & MENR & 64092 & 107803 \\
\hline 3 & Management of waste in Yuzny port, Odesa & Odesa City Admin. & 52806 & 50000 \\
\hline 4 & $\begin{array}{l}\text { Inventory and risk management of } \\
\text { contaminated sites }\end{array}$ & MENR & 121333 & - \\
\hline 5 & Modernization of Kyiv solid waste sector & Kyiv City Admin. & 1360000 & 2200000 \\
\hline 6 & $\begin{array}{l}\text { Rehabilitation of incineration plant } \\
\text { "Energia" }\end{array}$ & Kyiv City Admin. & 1342281 & - \\
\hline 7 & $\begin{array}{l}\text { Assistance to Ukrainian authorities in } \\
\text { management of contaminated sites }\end{array}$ & MENR & 650000 & - \\
\hline 8 & $\begin{array}{l}\text { Ukrainian National solid waste management } \\
\text { strategy }\end{array}$ & $\begin{array}{ll}\text { State } & \text { Housing } \\
\text { Committee } & \end{array}$ & 405323 & - \\
\hline 9 & $\begin{array}{l}\text { Solid waste sector strategy for Donetsk \& } \\
\text { Kharkiv }\end{array}$ & $\begin{array}{ll}\text { State } & \text { Housing } \\
\text { Committee }\end{array}$ & $\mathrm{n} / \mathrm{a}$ & - \\
\hline
\end{tabular}

Table 1. MSWM related projects listed in DANCEE Projects list (as of 2005)

The overall development objective in Donetsk and Kharkiv was improvement of MSWM and reduction of impacts from landfills serving these two cities following the EU principles already incorporated in relevant Ukrainian legislation. Assistance also was provided by installing a MSW processing plant in Kramatorsk, Donetsk Oblast. In response to a growing need to address MSWM problems in the Ukrainian capital, a DANCEE-financed project was initiated in 2001. The project was aimed at preparation of a MSWM strategy for Kyiv, upgrading of two landfills and demonstrating appropriate procedures for source separation and recycling/recovery of household waste. The main objective of the project was to develop a waste management system meeting stipulated performance standards and requirements in an economically and environmentally sustainable manner, and minimizes the overall adverse 
impact on the environment [14]. The project Rehabilitation of Incineration Plant, Energia, $K y i v$ was focused on increasing the combustion capacity, reducing air pollution and utilization of the produced heat in the district heating system.

The most valuable sector activities had deal with elaboration of the National Strategy on Solid Waste Management, initiated by DEPA together with the State Committee on Housing and Municipal Economy of Ukraine. The National Strategy was supposed to become a guiding document for structuring technical, institutional, regulatory and financial aspects for all Oblasts (regions) and Oblast cities. Unfortunately, the results of the project haven't been asked-for up to date due to unstable political situation.

The DANCEE sector assistance was given at state, region and community level. The role of communities was strengthened by two synergy projects focused on implementation of the Aarhus Convention (2001-2003) and supporting the Secretariat of the $5^{\text {th }}$ Environment for Europe Conference that took place in Kyiv in 2003 [13, 15]. Strengthening of the legal framework was reached by preparing the draft law of Ukraine "On Amendments to some Laws of Ukraine in the Area of Waste Treatment". The following legal documents were also revised: "On Local Self-governing", "On Insurance", The Code of Ukraine "On Administrative Violations" and other rules and regulations regarding hazardous waste. Changes of Danish governmental policy for financial support of environmentally sound activities in Eastern Europe led to a decrease in the number of development projects in Ukraine.

\subsection{Sweden}

Sweden is recognized as one of the leading countries in the field of waste management. According to the MENR report, cooperation with SwEPA in environmental protection area obtained the priority in Ukraine [2]. The aims and methods of cooperation of Sweden and Ukraine are included into document [17]. The financial support for realization of projects comes from the SIDA. Swedish support contributes to institutional capacity building at national, regional and local level and harmonization of legislation with the EU's regulatory directives. The objectives are reducing environmental pollution and increasing energy efficiency. Institutional cooperation has been considerably intensified during 2010-11. This has resulted in the adoption of the National Environmental Protection Policy till 2020 and the adoption of the detailed Action Plan till 2015 with definitive performance indicators. In spite of this, an important work component - establishment of a modern MSWM (incl. hazardous waste) system - has not become operational because of lacking support from the responsible MENR's MSWM Department. SIDA was informed that for the time toxic waste utilization has priority. Hence, important MSWM reforms were neglected [17].

\subsection{Finland}

In Finland, MSWM is well elaborated. Permissions for the placement of waste on landfills will be tightened within the next few years. Waste processing plants will become more and more important for waste reuse. Ukraine can profit from experiences on efficient operations with small volumes of waste over long distances gained in Lapland. The dialogue between Ukraine and Finland started in 1996 after signing the MOU in the field of environmental protection. Ukraine is very interested in heat and electricity gaining technologies through waste incineration. 
NEFCO was established in 1990 by Finland, Sweden, Denmark, Norway, and Iceland with the Headquarter office located in Helsinki. Corporation is intend to support private sector by funding cost- effective projects that reduces greenhouse gases emissions, decreases toxic pollutions and improves the environment of Baltic Sea. Fourteen percent of NEFCO projects were performed in Ukraine aimed at saving environment, energy and resources. The general objective for NEFCO's participation in waste projects is to minimize the amount of waste and improved treatment of waste by sorting, recycling and re-use. Projects may include both household and industrial waste that may contain paper, plastics, chemicals etc.

\subsection{Norway}

Norway, Sweden and Denmark have developed their waste technology parallel in most respects. Using the resources from waste will be important to Ukraine in the years to come. Norway has great experience in implementation of energy-saving technologies and Cleaner Production in the southern regions of Ukraine provided by Norwegian Society of Graduate Technical and Scientific Professionals (TEKNA). The Embassy's Small Project Fund provided support for local initiatives in Ukraine and Belarus.

\section{OBSTACLES FOR COOPERATIONS}

The core problem of MSWM in Ukraine is that a National strategy is not yet well-defined. It turns to violations of technical regulations for solid waste deposits, lack of available sites for building new landfills, old-fashioned garbage trucks and outmoded containers for collecting municipal waste. There is no sufficient communications between State and local government officials, local communities and businesses that operates in the MSW sector.

Another complication is that the structure and responsibilities of the MENR repeatedly changed. During 2008-2011 four ministers were exchanged including the key personnel. Since the end of 2010 institutional reorganization took place in all bodies of the Ukrainian Government. The new institutional structures need now to be completed by appropriate coordinating bodies and to renew smoothly working personal contacts. To enable the implementation of the Environmental Strategy and National Action Planes the governmental structures and their efficiency have to be seriously strengthened.

Project finance is difficult in Ukraine since borrowers cannot rely on State support for their projects because of lacking legal security. IFIs claim that frequent changes in legislation, cumber approval mechanism from the Ministry of Finance and insufficient staff capacity prevent the implementation of planned projects. Project proposals lack modern concepts for pre-feasibility studies.

The fact that environmental issues can actually contribute to economic growth (MSW recycling and processing industry creates many jobs) remains underestimated by Ukraine's policymakers. The exploitation of secondary natural resources is hindered because of immature and inadequate infrastructures, low motivation for recycling, inactive bodies on different levels, and business risks for implementation. The low public awareness and motivation for changes additionally aggravate the implementation of sustainable solution.

\section{RECOMMENDATIONS}

Despite domestic political instability, Ukraine maintains a firm political course towards Europe. The Eastern partnership project indicates that the EU is willing to intensify its 
relationships with Ukraine. Environmental cooperation of Ukraine with BSR countries becomes more distinct in international politics, and it can radically change the state of affairs in Europe. This strategy should proceed with the continuation of the Ukrainian course towards European integration. The waste related EU Directives as [18] and [19, 20] contain nearly all relevant issues and can be considered as the main incentives to improve the MSWM sector and to fulfill important requirements for the EU integration. The aim of common arrangements will be combined with the obligations, which Ukraine has already overtaken, for the sake of risks minimization in the conditions of political instability.

Inconsistence of the state policy in MSWM conveys a "bottom-up" strategy at local level. Nowadays, the problem of MSWM is a top priority for many local communities that think on raising public awareness, reducing the amount of household waste and developing local MSWM programs. Ukrainian environmental policy should focus on building broad-based public support for sustainable MSWM and demonstrate the social and economic loads of ignorance and should provide adequate allocations from the State Budget for effective environmental measures.

Scientific institutions and NGOs are taking a leading role in international environmental cooperation and obtaining financial aid due to their independence of political constrains. Their efforts in communities' capacity building and dissemination of information on the current status of MSWM in European countries are well recognized. It will be more attractive for donor organizations to establish a stakeholders' platform for more efficient financial management and trust of various social groups, local government and business.

Public awareness building is important because there seemingly is a profound lack of general know-how on the urgent need of waste minimization, reuse, recycling and recovery of materials and energy starting with consumers' waste avoidance and waste separation. Commercial advantages and benefits for humans and nature should be made clear for all through well-targeted educational and information campaigns and stakeholders' involvement in the development of the municipal waste management plans.

\section{ACKNOWLEDGMENTS}

The Authors wish to thank the Swiss National Scientific Fund for financial support obtained for the SWC-ENV-IND project \# IZ73Z0_128178/1 that makes avialable this research.

\section{REFERENCES}

[1] Troschinetz A, Mihelcic J.R. 2009. Sustainable recycling of municipal solid waste in developing countries Waste Management N 29, pp. 915-923

[2] Government publication. 2011. Національна доповідь про стан навколишнього природного середовища в Україні у 2010 році. (National Report. 2011. On the State of Environment in Ukraine in year of 2010, p. 136. Kyiv, Ukraine (in Ukrainian)

[3] EU/Ukraine Action Plan, Ch. 2.5. Transport, energy, information society and environment. Electronic resource: http://ec.europa.eu/world/enp/pdf/action_plans/ukraine_enp_ap_final_en.pdf

[4] Михайленко В.П, Алексеевец И.Л. Денафас Г. 2012. Особенности образования твердых бытовых отходов в Украине (Features of Municipal Solid Waste Generation in Ukraine) In: Proceedings of WasteEco-12, 28 March, 2012. Kharkiv, Ukraine, http://waste.ua/eco/2012/municipal-waste/ukraine/ (in Ukrainian) 
[5] Закон України N 2818-VI, від 21.12.10 Про Основні засади (стратегія) державної екологічної політики України на період до 2020 року., Law of Ukraine N 2818-VI of 12.21,10 On The Basic Principles (strategy) of State Environmental Policy of Ukraine till 2020. (in Ukrainian).

[6] The Outline Convention on Trans- frontier Co-operation between Territorial Communities or Authorities. Electronic resource:

http://conventions.coe.int/treaty/Commun/QueVoulezVous.asp?CL=ENG\&NT=106

[7] Waste Governance - European neighborhood and partnership instrument (ENPI) East.

Web site: http://wastegovernance.org/main2_eng.html

[8] Андрусевич А., Андрусевич Н., Козак 3. 2009. Довідник чинних міжнародних договорів України у сфері охорони довкілля. Львів -203 с. (Andrusevych A.,

Andrusevych N., Kozak Z. (2009) Guide on International Environmental Treaties to Which Ukraine is a Party - Lviv, - 203 p. Available:

http://www.rac.org.ua/en/activities/publications/guide-on-international-environmentaltreaties-to-which-ukraine-is-a-party/ (in Ukrainian)

[9] ENPI-CBC. Cross-border Cooperation Programme Poland-Belarus-Ukraine, 2007-2013.

Electronic resource: http://cu4eu.net/_DOC/Info/Instruments/ENPI/CBC/PL-BY-

UA/PLBYUA_EN.pdf

[10] Обращение с бытовыми отходами (Solid waste management. Web resource: http://www.waste-utilisation.org/?lan=rus\&m=1 (in Russian)

[11] Denafas G., Vitkauskaitė L., Jankauskaitė K., et al. 2011. Seasonal changes of municipal solid waste generation and content: case study for Lithuanian, Ukrainian, Georgian and

Russian cities. In: Proceedings of "Sustainable municipal solid waste management in Eastern Europe - future perspectives" May 18-20, 2011. Kyiv. Ukraine. (in English)

[12] DEPA. 2001. Danish Environmental Assistance and Global Conventions. Synergy and

Prioritized Action Areas. Frederiksberg Bogtrykkeri, - 76 p. Available at:

http://www2.mst.dk/udgiv/publications/2001/87-7944-437-7/pdf/87-7944-438-5.pdf (in

English)

[13] DANCEE Project list. 2005. Source: MENR of Ukraine (in Ukrainian/English)

[14] COWI electronic resource:

http://www.cowi.com/menu/project/WaterandEnvironment/Solidwastemanagement/Pages/Sol idWasteManagementImprovementInKyivUkraine.aspx

[15] Governmental publication. Pedersen P. Lund H. 2003. Environment in Ukraine:

Problems and Challenges. DEPA -55 p. Available at:

http://www2.mst.dk/common/Udgivramme/Frame.asp?http://www2.mst.dk/udgiv/publication s/2003/87-7972-725-5/html/kap03_eng.htm

[16] Ministry for Foreign Affairs of Sweden. 2008. Strategy for Swedish development cooperation with Ukraine, 2009-2013. Available at:

http://www.sweden.gov.se/sb/d/574/a/94005

[17] SIDA Environment Program Status Review (personal communications)

[18] Directive 2008/98/EC on waste (Waste Framework Directive)

[19] Landfill Directive 99/31/EC

[20] Directive on Packaging and Packaging Waste 94/137/EEC 